\title{
Effects of Concept Mapping and Cooperative Mastery Learning Strategies on Students' Achievement in Photosynthesis and Attitudes towards Instructional Strategies
}

\author{
Emmanuel Bizimana \\ African Centre of Excellence for Innovative Teaching and Learning Mathematics \\ and Science (ACEITLMS), \\ University Rwanda - College of Education (UR-CE), Rwanda \\ Dieudonné Mutangana! \\ Department of Biology, \\ University Rwanda - College of Science and Technology, Rwanda \\ Adrian Mwesigye \\ Department of Educational Foundations and Psychology, \\ Mbarara University of Science \& Technology (MUST), Uganda
}

\begin{abstract}
Students' low performance in biology perturbs many teachers and other stakeholders. This has sparked research into learning strategies that might be utilized to improve students' performance in the subject. This study investigated the effects of Concept Mapping (CM) and Cooperative Mastery Learning (CML) on students' achievement in photosynthesis. A pre-test, post-test, non-equivalent control group, quasi-experimental design was used. A sample of 449 students was drawn from the population of 6,708 senior two secondary students (SS2) in Nyamagabe district, Rwanda. Photosynthesis Achievement Test (PAT) $(K R-21=.82)$, Attitude Towards Concept Mapping Questionnaire (ATCMQ), and Attitude Towards Cooperative Mastery Learning Questionnaire (ATCMLQ) were used for data collection. Data were analyzed mainly using mean and standard deviation, Analysis of covariance (ANCOVA), and t-test. Findings revealed that the students who were exposed to the $\mathrm{CM}$ and $\mathrm{CML}$ attained significantly higher mean achievement scores in the PAT than those exposed to Conventional Teaching Methods $(\mathrm{CTM})\left(\mathrm{F}_{(2,445)}=385.242, \mathrm{p}<0.05\right)$. The CM group students achieved significantly better than the CML group. Moreover, there was no significant interaction effect between instructional strategies and gender in achievement $\left(\mathrm{F}_{(2,442)}=.344, \mathrm{p}>\right.$ $.05)$. The students showed a significant and positive attitudes towards the use of $\mathrm{CM}$ over the use of $\mathrm{CM}(\mathrm{t}=5.8, \mathrm{p}<.05)$. Thus, the $\mathrm{CM}$ and $\mathrm{CML}$
\end{abstract}


are effective strategies for successful and meaningful photosynthesis learning. It was recommended among other things that the biology teachers should use the CM and CML to enhance students' achievement in biology especially in difficult and abstract concepts like photosynthesis.

Keywords: achievement; concept mapping; conventional teaching methods; cooperative mastery learning; photosynthesis

\section{Introduction}

Biology is important for everyone's lives, and it is becoming increasingly prominent in school science classes. It has improved all elements of life on Earth and assisted us in better understanding Mankind and other organisms (Joda, 2019). Besides, a solid understanding of biology is required for careers in medical, pharmacy, nursing, agriculture, forestry, biotechnology, nanotechnology, and other fields (Joda, 2019), and therefore, the importance of biology in the growth of a country cannot be overstated.

Students learn vital science topics in biology that provide the foundation of their comprehension of a variety of Earth processes. One of them is photosynthesis; a crucial process that occurs in plants. According to Aboho et al. (2013) and Johnson (2016), photosynthesis is a process in which the energy in sunlight is gathered and converted into organic compounds to sustain metabolic activities in all living organisms. Thus, understanding the photosynthesis concept is crucial to understanding many elements of biological systems. Despite the importance of photosynthesis, studies have found that photosynthesis is a tough concept for students to acquire and understand (Etobro \& Fabinu, 2017; Hadiprayitno et al., 2019; Kyado et al., 2019). Besides, studies have also revealed that students have a lot of misconceptions regarding photosynthesis (Akçay, 2017; Métioui et al., 2016; Nasution, 2018).

The ineffective instructional strategy used by biology teachers is unmistakably to blame for students' perceptions of difficult biology concepts and misconceptions which in turn lead to low achievement in biology. Angura and Abakpa (2018) submitted that poor students' achievement and misconceptions in science subjects are traceable to instructional approaches adopted by teachers. The use of an effective instructional method that actively and socially involves students in learning plays a vital role in the mastery of biological concepts. This is based on constructivist theory by Vygotsky (1978) which emphasizes the importance of learner's active participation in learning and on social learning theory by Bandura (1977), which proposes that new behaviours can be acquired by observing and imitating others. Thus, a novel teaching strategy that emphasizes active and social learning is required.

Some of the constructivist-based teaching strategies include Concept Mapping (Ajaja, 2011, 2013; Awofala, 2016; Wang et al., 2017), and Cooperative Mastery Learning (Goreyshi et al., 2013; Keter, 2013; Khan \& Masood, 2015).The CM is an instructional strategy that entails thinking in terms of graphical representation of 
the relationship among concepts (Novak \& Cañas, 2009). The CML, on the other hand, is a hybridized strategy of cooperative and mastery learning in which students who fail to achieve mastery are required to relearn together in small groups with their peers who have attained the mastery (Khan\& Masood, 2015). Therefore, both constructivist and social learning theories can be used to explain the efficacies of CM and CML. Different researchers have found that using the $\mathrm{CM}$ and CML improve science outcomes, both of which have been proven to be superior to CTM (Ajaja, 2011, 2013; Awofala, 2016; Dashne \& Sinaa, 2019; Goreyshi et al., 2013; Keter, 2013; Khan \& Masood, 2015; Woldeamanuel et al., 2020). Although, these strategies can enhance students' achievement in some topics and some countries, rarely has any been implemented on photosynthesis generally, in secondary schools in Rwanda, and the study area in particular. Besides, no comparative efficacies of these strategies have been revealed in any study including international students and Rwandan students.

Gender disparities in science education have been documented for a long time, and they still exist today (Jia et al., 2020; Stevenson et al., 2021). According to a recent review, sex disparities in student achievement still exist, and they are primarily due to the teaching strategies used by teachers (Uchegbue \& Amalu, 2020). Consequently, biology teachers must be aware of these differences in how students learn biology and respond appropriately. Moreover, the evidence from the revised literature has not shown any conclusion on the interactive effect of teaching strategies and gender on students' achievement (Adeyemi \& Cishe, 2017; Bot \& Eze, 2016; Çömek et al., 2016). Likewise, the issues on students' attitudes toward the $\mathrm{CM}$ and $\mathrm{CML}$ have received little empirical attention (Martins-Omole et al., 2016). In response to these challenges, this study investigated the effects of CM and CML on gender, the interaction effects of treatment and gender on students' achievement in photosynthesis, and the attitudes of students towards the CM and CML. Based on the premises mentioned above, the following research questions were addressed in this research:

1. What are the effects of the treatments (CM, CML, and CTM) on students' achievement in photosynthesis?

2. What are the relative effects of treatments and gender interaction on students achievement in photosynthesis?

3. What are the attitudes of students towards the use of $\mathrm{CM}$ and $\mathrm{CML}$ in teaching and learning photosynthesis?

\section{Methodology}

\subsection{Research Design}

In this study, a mixed-method approach was adopted. Data from both qualitative and quantitative sources were gathered and examined. Mixed methods research, according to Creswell (2014), refers to situations in which a researcher gathers, analyses, and integrates both qualitative and quantitative data in a single study. The quantitative data consisted of student achievement on both the pre-test and post-PAT, while the qualitative data consisted of openended questionnaire responses. A pre-test-post-test non-equivalent comparison group design (Creswell, 2014) was employed in this study. This design was 
appropriate for this study because the students were taught in their already formed intact classes. It was not ethical to randomly compose and group students or disrupt classes already in existence. Thus, the use of intact classes made it possible to experiment with some of the classes while the other classes acted as the comparison group. Table 1 displays the study research design layout.

Table 1: Research Design Layout

\begin{tabular}{lccc}
\hline Groups & Pre-Test & Treatment & Post-Test \\
\hline EG1 & $\mathrm{O}_{1}$ & $\mathrm{X}_{1}$ & $\mathrm{O}_{2}$ \\
EG2 & $\mathrm{O}_{1}$ & $\mathrm{X}_{2}$ & $\mathrm{O}_{2}$ \\
CG & $\mathrm{O}_{1}$ & $\mathrm{X}_{\mathrm{O}}$ & $\mathrm{O}_{2}$ \\
\hline
\end{tabular}

Where:

EG1: Experimental Group 1

EG2: Experimental Group 2

CG: Comparison Group

X1: Treatment for Experimental Group 1 using Concept Mapping

X2: Treatment for Experimental Group 2 using Co-operative Mastery Learning

$\mathrm{XO}$ : Treatment for comparison group using Conventional teaching method (teachers' regular teaching methods)

O1: Pre-test

O2: Post-test

\subsection{Research Participants}

The study was carried out in Nyamagabe district, Southern Province, Rwanda. Purposive sampling was used in selecting seven co-educational secondary schools out of 46. A purposeful sampling of the schools was based on whether they were boarding or mixed schools. The 449 SS2 students from seven schools were assigned to the experimental and comparison groups using a simple random sampling technique. All intact classes of SS2 students from each of the selected schools were used in the study. Thus, 151 students in their intact classes were assigned to EG1. Then, 144 students were assigned to EG2 and 154 students to CG. Table 2 shows the sample distribution for the study.

Table 2: Study's Sample Distribution

\begin{tabular}{lccc}
\hline Group & Male & Female & Total \\
\hline Concept Mapping (CM) (EG1) & 74 & 77 & 151 \\
Cooperative Mastery Learning (CML) (EG2) & 73 & 71 & 144 \\
Conventional Teaching Method (CTM) (CG) & 78 & 76 & 154 \\
\hline
\end{tabular}

\subsection{Research Instruments and Validation}

The Photosynthesis Achievement Test (PAT), which acted as both a pre-and post-test, the Attitude towards Concept Mapping Questionnaire (ATCMQ), and 
Attitude Towards Cooperative Mastery Learning Questionnaire (ATCMLQ) were utilized to collect data (See Appendix 1 and 2). The pre-PAT was used to establish the students' knowledge baseline as well as the academic homogeneity of the two groups before intervention, while the post-PAT was used to determine achievement levels of students after the intervention. Each PAT (i.e., the pre-test and post-test) had 40-multiple-choice items. These items were selected from the question pool in the SS2 student textbook and were developed based on the objectives of the unit of photosynthesis as specified in Rwanda's Biology Curriculum for Senior Secondary School two (SS2) students in Competence-Based Curriculum (Rwanda Education Board [REB], 2015). The PAT items were examined using the table of specifications which ensured the content validity of PAT (Fives \& DiDonato-Barnes, 2013). The PAT was developed by researchers and validated by two secondary school biology teachers with teaching experience of over 10 years and two experts in biology education and test and measurement. Thereafter, it was pilot-tested where the KR-21 reliability was 0.82 .

Following the post-test, the experimental groups were given the ATCMQ and ATCMLQ to complete. Each questionnaire had 18 Likert scale items with the following options: 'strongly disagree,' 'disagree,' 'neutral,' 'agree,' and' strongly agree.' The responses were given scores of 1,2,3,4, and 5 respectively. The 18 Likert scale items were supplemented with open-ended questions to learn more about students' opinions after the intervention had been implemented. The questionnaire's entire purpose was to assess students' attitudes toward the use of the CM and CML.

\subsection{Data Collection Procedures}

The data collection procedure for this study was divided into the following five stages for the sake of clarity:

\subsubsection{Preliminary Stage}

During this stage, the researchers sought permission from the authorities of the schools whose students would be participating in the study. This allowed the researchers to administer treatments and tests to intact classes. Seven regular biology teachers in the selected schools who served as research assistants in the study were trained and orientated during the first week. The teachers performing the experimental treatment were separately trained on the use of CM, CML.

Specifically, teachers for the CM group were taught about the CM, its benefits, how it is used to establish relationships between concepts, and the procedures to take while using the CM-based teaching strategy as indicated by Novak and Gowin (1984). They were also provided with some samples of computer-made concept maps on the topics they would be teaching (Figure 1).

Teachers in the CML group were informed about the attributes of cooperative and mastery strategies as well as the descriptive information of the CML procedures. The focus was on grouping students to allow them to learn in cooperative learning groups, with the content divided into small topics to be 
covered one by one. A set of quizzes was also used to determine whether the objectives had been met or whether mastery had been achieved before moving on to the next topic. Those who did not achieve the expected mastery level would be remedied by their peers who had demonstrated mastery. The training lasted for four days. The research assistants were given lesson plans for the duration of the study, as well as for instructions on how to use them to teach students in the selected schools. Lesson plans for CM and CML strategies were used by teachers who were undergoing experimental treatment respectively. The teachers in the comparison groups used lesson plans prepared for CTM. The research assistants were also given instructions on how to conduct the pre, posttests as well as questionnaires.

\subsubsection{Pre-Treatment Stage}

With the assistance of the research assistants, the PAT was administered as a pre-test during the second week. The PAT consisted of 40 multiple-choice questions, and students were given $1 \mathrm{~h} 30^{\prime}$ to complete it. Respondents were given verbal instructions on how to answer questions in addition to the written instructions on the question papers. Before treatment, students in the CM group received one week of training. The research assistants explained the $\mathrm{CM}$ strategy, defined and explained the vocabularies associated with the concept maps such as concepts, propositions, relationships, hierarchy, and cross-links, from general to specific. Specifically, the emphasis was put on how to create concept maps. Students were given opportunities for more guided practice exercises along with teachers' feedback. Students individually created concept maps using the words given by the teacher to make them conversant with CM. The teachers examined student-made maps, identified and corrected errors, and the students' best maps were displayed on the class walls.

For the CML, students were put into groups of mixed ability and then trained by the teachers on cooperative learning skills and mastery learning for also one week before the treatment period.

\subsubsection{Treatment Stage}

The third to sixth weeks were for the treatment in the experimental and control groups. The photosynthesis unit topics were taught in all study groups. In the $\mathrm{CM}$ group, the teaching-learning process was composed of an introduction, presentation, and summarization. At the end of each teaching, teachers assessed every day's lesson through a concept map. 


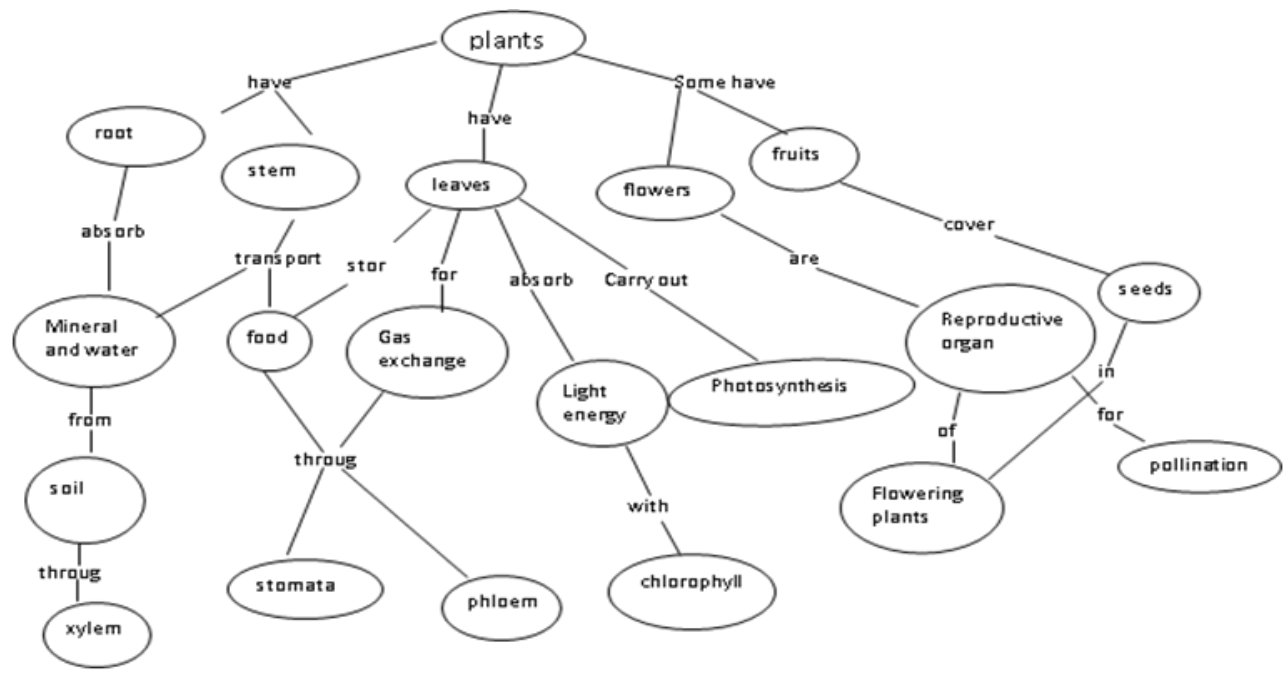

Figure 1: Researchers' 2021 Computer-Made Concept Map about Parts of Plants and their Functions

This process continued and students constructed concept maps on all covered topics. After the unit of photosynthesis was completed, students constructed a more general concept map by pooling together all the maps they had constructed during every topic lesson. A reference concept map was given to cross-check their concept maps.

In the CML group, students were taught the same content as in CM groups using a combination of cooperative and mastery learning strategies. The initial learning and practice phase was implemented in mastery, and then in cooperative settings. Students worked individually on practice questions. After, students were individually tested for the topics learned with a diagnostic test and the groups received corrective feedback information. Those who attained the pre-set criterion level of mastery ( $80 \%$ correct responses) were asked to assist the low achievers (those who scored less than $80 \%$ correct response) to remedy their difficulties. After correctives, students were retested on a parallel form of the test. Following the same practice on each topic, the class teachers accomplished teaching the unit on photosynthesis.

The students in the CTM group were exposed to the same unit as the experimental groups during the period under study. However, teachers neither utilized $\mathrm{CM}$ nor $\mathrm{CML}$ in their regular teaching practices which normally involved teacher's presentations, discussions, and practical work. Treatment lasted for 4 weeks. Besides and throughout the treatment period, the research assistants were supervised to ensure smooth learning and proper execution of teaching strategies/methods and procedures in all classes.

\subsubsection{Revision Stage}

At this point, the research assistants were asked to go over the topics with the students again to get them ready for the post-test. All of the topics covered during the study were thoroughly revised. This was done in the seventh week. 


\subsubsection{Post-Test Stage}

The eighth week was marked by the administration of the PAT as a post-test, a reshuffled version of pre-PAT concurrently in all schools used in the study. Particularly, the ATCMQ and ATCMLQ were also administered in the CM and CML groups respectively to assess their attitudes towards the CM and CML.

\subsection{Data Analysis}

Data analysis involved both quantitative and qualitative aspects. Statistical analysis such as mean and standard deviation, Analysis of Covariance (ANCOVA), and t-test were used to summarize quantitative data. Where the main effect was significant, Scheffe's test was employed to ascertain the direction of the significant difference among the means of the groups (Creswell, 2014). Besides, the Eta squared was used to measure the effect size. In the evaluation of the eta squared, the effect size was interpreted as follows: $0.01<\eta 2<0.06$ : small; $0.06 \leq \eta 2<0.14$ : moderate; $0.14 \geq \eta 2$ : big (Cohen, 1988). To analyze qualitative data, content analysis was used to classify semantic categories into sub-themes and themes. Following that, the developed themes were gathered and synthesized using the semantic category to which they refer (Creswell, 2014).

\section{Results}

Pre-test scores were used to ensure that the experimental and control groups were homogeneous. The PAT pre-test scores for the study groups are presented in Table 3 below.

Table 3: Analysis of Variance (ANOVA) of the Pre-Test Scores

\begin{tabular}{lrrrrr}
\hline Source of Variation & Sum of Squares & df & Mean Square & F & Sig. \\
\hline Between Groups & 123.963 & 2 & 61.981 & 1.670 & .189 \\
Within Groups & 16549.264 & 446 & 37.106 & \\
Total & 16673.227 & 448 & & \\
\hline
\end{tabular}

Table 3 shows that the three groups' means are not statistically different $\left(\mathrm{F}_{(2,446)}=\right.$ $1.670, p>0.05)$. As a result, it was discovered that the three groups started with equivalent means, indicating that the students in the three groups were of equal ability before interventions. To determine the effect of treatment, the pre-test and post-test scores were compared (Table 4).

Table 4: Descriptive Statistics of Students' Post-Test Scores

\begin{tabular}{lcccccc}
\hline \multirow{2}{*}{$\begin{array}{c}\text { Method of } \\
\text { teaching }\end{array}$} & \multicolumn{3}{c}{ Pre-test } & \multicolumn{4}{c}{ Post-test } & \multirow{2}{*}{$\begin{array}{c}\text { Mean } \\
\text { Gain }\end{array}$} \\
\cline { 2 - 6 } & $\mathrm{N}$ & Mean & SD & Mean & SD & \\
\hline CM & 151 & 30.58 & 7.23 & 73.66 & 9.63 & 43.08 \\
CML & 144 & 29.84 & 6.34 & 63.16 & 7.03 & 33.32 \\
CTM & 154 & 29.31 & 4.38 & 48.38 & 6.77 & 19.07 \\
\hline
\end{tabular}


Table 4 reflects that the average mean of the students instructed with the $\mathrm{CM}$ increased by 43.08 points, and that of the CML was increased by 33.32 points while that of the CTM was then increased by 19.07 points from the pre- to postPAT. These findings showed that the students who were taught photosynthesis using $\mathrm{CM}$ achieved higher than those taught using CML, whereas students who were taught using CML achieved higher than those taught using the CTM group.

The effects of treatments on students' achievement in photosynthesis from the pre-PAT to post-PAT were investigated via ANCOVA analysis. The latter showed that a statistically significant difference existed in post-test scores among the groups $\left(\mathrm{F}_{(2,445)}=385.242, \mathrm{p}=0.00<0.05\right)$. Thus, $\mathrm{CM}, \mathrm{CML}$, and $\mathrm{CTM}$ impacted students' achievement after controlling for the pre-test.

Table 5: ANCOVA of the Achievement of Students Exposed to CM, CML, and the CTM

\begin{tabular}{lcccccc}
\hline Source & $\begin{array}{c}\text { Type III Sum of } \\
\text { Squares }\end{array}$ & Df & $\begin{array}{c}\text { Mean } \\
\text { Square }\end{array}$ & F & Sig. & $\begin{array}{c}\text { Partial Eta } \\
\text { Squared }\end{array}$ \\
\hline Corrected Model & $49209.682^{\mathrm{a}}$ & 3 & 16403.227 & 258.610 & .000 & .635 \\
Intercept & 67913.498 & 1 & 67913.498 & 1070.709 & .000 & .706 \\
Pre-test & .161 & 1 & .161 & .003 & .960 & .000 \\
Treatment & 48870.646 & 2 & 24435.323 & 385.242 & .000 & .634 \\
Error & 28225.694 & 445 & 63.429 & & & \\
Total & 1782252.500 & 449 & & & & \\
Corrected Total & 77435.375 & 448 & & & & \\
\hline
\end{tabular}

a. R Squared $=.635$ (Adjusted R Squared $=.633$ )

The index value of eta-squared $\left(\eta^{2}\right)=.634$ corresponded to the big effect size (Cohen, 1988), which means that $63.4 \%$ of the variance in the post-achievement is explained by the treatments. However, the findings in Table 5 did not show the origin of the differences found in the ANCOVA test. Thus, Scheffe's test was used to analyze paired contrast (Table 6).

Table 6: Pair-Wise Comparisons of Students' Scores

\begin{tabular}{ccccc}
\hline $\begin{array}{c}\text { (I) Group of } \\
\text { students }\end{array}$ & (J) Group of students & Mean Difference (I-J) & Std. Error & Sig. $^{\text {b }}$ \\
\hline \multirow{2}{*}{ CTM } & CM & $-25.280^{*}$ & .915 & .000 \\
& CML & $-14.778^{*}$ & .924 & .000 \\
\multirow{2}{*}{ CM } & CTM & $25.280^{*}$ & .915 & .000 \\
& CML & $10.502^{*}$ & .929 & .000 \\
\multirow{2}{*}{ CML } & CTM & $14.778^{*}$ & .924 & .000 \\
& CM & $-10.502^{*}$ & .929 & .000 \\
\hline
\end{tabular}

Based on estimated marginal means

*. The mean difference is significant at the .05 level.

b. Adjustment for multiple comparisons: Bonferroni. 
Table 6 shows that the mean difference between the CM and CML groups (10.502) was lower than the mean difference between the CM and CTM groups (25.280). This showed how the three strategies to improving students' photosynthetic achievement differ, with $\mathrm{CM}$ having the highest effect, followed by CML, and finally CTM. As a result, there is a substantial difference in the effects of CM, CML, and CTM on students' achievement.

Table 7: Mean and Standard Deviation of Students' Achievement Sores by Teaching

Strategy and Gender

\begin{tabular}{|c|c|c|c|c|c|c|c|}
\hline \multirow[t]{2}{*}{ Teaching strategy } & \multirow[t]{2}{*}{ Gender } & \multicolumn{3}{|c|}{ Pre-test } & \multicolumn{2}{|c|}{ Post-test } & \multirow[t]{2}{*}{ Mean Gain } \\
\hline & & $\mathbf{N}$ & Mean & SD & Mean & SD & \\
\hline \multirow[t]{2}{*}{$\mathrm{CM}$} & Male & 74 & 30.67 & 7.07 & 74.57 & 6.65 & 43.9 \\
\hline & Female & 77 & 30.49 & 7.43 & 72.77 & 6.80 & 42.28 \\
\hline \multirow[t]{2}{*}{ CML } & Male & 73 & 30.72 & 5.37 & 63.52 & 6.27 & 32.8 \\
\hline & Female & 71 & 28.94 & 7.13 & 62.78 & 7.76 & 33.84 \\
\hline \multirow[t]{2}{*}{ CTM } & Male & 78 & 29.47 & 4.74 & 47.96 & 8.73 & 18.49 \\
\hline & Female & 76 & 29.13 & 4.01 & 48.81 & 10.56 & 19.68 \\
\hline
\end{tabular}

When the data in Table 7 is broken down by gender, males appeared to do better in the CM group, while females appeared to achieve better in the CML and CTM groups. From pre-PAT to post-PAT, the males in the CM group increased their mean by 43.9 points, while the females increased it by 42.28 points. Males increased their mean by 32.8 points, while females increased it by 33.84 points in the CML group. Males improved their mean by 18.29 points in the CTM group, while females improved their mean by 19.68 points. The main effects of treatments, gender, and their interactions on achievement in photosynthesis were examined via two-way ANCOVA (Table 8).

Table 8: Summary of ANCOVA of Interaction Effect of Treatment and Gender on Students' Achievements in Photosynthesis

\begin{tabular}{lcccccc}
\hline Source & $\begin{array}{c}\text { Type III Sum of } \\
\text { Squares }\end{array}$ & Df & $\begin{array}{c}\text { Mean } \\
\text { Square }\end{array}$ & F & Sig. & $\begin{array}{c}\text { Partial Eta } \\
\text { Squared }\end{array}$ \\
\hline Corrected Model & $49379.917 \mathrm{a}$ & 6 & 8229.986 & 129.659 & .000 & .638 \\
Intercept & 67668.316 & 1 & 67668.316 & 1066.081 & .000 & .707 \\
Pre-test & .609 & 1 & .609 & .010 & .922 & .000 \\
Treatment & 48907.912 & 2 & 24453.956 & 385.260 & .000 & .635 \\
Gender & 36.150 & 1 & 36.150 & .570 & .451 & .001 \\
Treatment * Gender & 135.618 & 2 & 67.809 & 1.068 & .344 & .005 \\
Error & 28055.459 & 442 & 63.474 & & & \\
Total & 1782252.500 & 449 & & & & \\
Corrected Total & 77435.375 & 448 & & & & \\
\hline
\end{tabular}

a. R Squared $=.638$ (Adjusted R Squared $=.633$ ) 
Based on the ANCOVA results (Table 8), the hypothesis was rejected for the independent variable of the treatments $\left(\mathrm{F}_{(2,442)}=385.260, \mathrm{p}<.05\right)$, but was accepted for the gender $\left(\mathrm{F}_{(1,442)}=.451, \mathrm{p}>.05\right)$ and gender*treatment interaction $\left(F_{(2,442)}=.344, p>.05\right)$. The results also indicated that gender had no significant effect on the students' achievement. Likewise, the effect of the gender*treatment interaction did not influence achievement either. It means that the effect of the treatments on the achievement did not vary according to the students' gender.

To examine whether there was a significant difference in the attitudes of students towards the use of the CM and CML, both ATCMQ and ATCMLQ scores were subjected to an independent sample t-test (Table 9). Before performing a t-test, the data were checked to see if they were normally distributed by computing the skewness and kurtosis, and coefficients. The analysis revealed that these coefficients were .525 and - .082 and .203 and .157, respectively. Therefore, the questionnaire scores looked to be normally distributed (Hinton et al., 2014).

Table 9: Independent Sample T-Test Analysis on Attitudes towards the Use of CM and CML Strategies in the Teaching and Learning Photosynthesis

\begin{tabular}{cccccccc}
\hline Strategy & N & Mean & Std. Deviation & Std. Error & t-value & df & Sig. \\
\hline CM & 151 & 60.79 & 5.69 & .463 & 5.888 & 293 & .000 \\
CML & 144 & 56.61 & 6.49 & .541 & & &
\end{tabular}

The results in Table 9 indicated that students preferred the use of the $\mathrm{CM}$ to the use of CML strategies in the teaching of biology. The observed mean score of 60.79 for $\mathrm{CM}$ against 56.61 for CML demonstrates this. The test's observed level of significance is $0.000(\mathrm{p}<0.05)$.

\subsection{Analyses of the Open-Ended Questions}

Descriptive and content analyses were used to examine the students' responses to the open-ended questions. Hence, the students' opinions were divided into words, sentences, and paragraph analysis units, which were then evaluated. The theme and concepts had been chosen. The researchers tallied the number of times the associated terms were mentioned and analyzed the data. The findings were backed up by the students' viewpoints.

The question asked to the CM group was as follows: "How do you think the CM contributed to your understanding of photosynthesis? Please briefly explain your answer". All students reported that using CM aroused their interest and made the lessons very interesting. Quotes from students' expressions are given below:

- The CM strategy made a positive contribution to me, we constructed concept maps ourselves. 
- The concept maps attracted my interest in photosynthesis subject and increased my understanding.

- Learning has become easier for me because we do a lot of activities.

- I remember most of the photosynthesis-related concepts we learned in our class.

When they were asked to rate their understanding of photosynthesis, $31(20.0 \%)$ students in the CML group reported a very good understanding of the concept, meanwhile 89 (58.9\%) reported a good understanding of the concept, and 9 $(6.0 \%)$ reported unsatisfactory understanding.

The question asked to the CML group was as follows: "How do you think the CML contributed to your understanding of photosynthesis? Please briefly explain your answer". All students reported that the application of the CML affected them positively. Quotes from students' expressions are given:

- The discussions and activities were very interesting, the lessons were enjoyable and I felt free and relaxed.

-I remember most of the things we discussed

- Because I have the opportunity to debate and compare my thoughts with others, I have learned new things from my classmates.

-When I made a mistake, my group members assisted me by giving me other explanations for the situation.

When they were asked to rate their understanding of photosynthesis, 43 (29.9\%) students in the CML group reported a very good understanding of the concept, whereas $78(54.2 \%)$ reported a good understanding of the concept, while only 4 $(2.8 \%)$ students reported unsatisfactory understanding of photosynthesis.

\section{Discussion}

The findings of this study revealed that the students in the CM and CML groups achieved significantly higher than those in the CTM group. This finding is consistent with prior research findings, which showed that $\mathrm{CM}$ and CML are better than CTM at enhancing students' achievement in science concepts (Awofala, 2016; Keter, 2013; Khan \& Masood, 2015). The outstanding achievement of students exposed to CM and CML over those taught using CTM may be attributed to their efficiency in their activity orientations. Both $\mathrm{CM}$ and CML allowed students the opportunities to participate and to involve actively in the teaching and learning process. This is in line with the views of Mokiwa and Agbenyeku (2019) who submitted that activity-oriented instructional strategies aid understanding of the concept taught which in turn supports the findings of this study. Contrarily to this, CTM most of the time enforces students to learn through rote memorization techniques which do not help students understand the meaning and the relationship among the concepts, and therefore they are subject to easily forget them from their mind which leads to poor achievement (Schmid \& Telaro, 2018).

The findings of this study also indicated that students who were taught using $\mathrm{CM}$ achieved significantly higher than their counterparts who used CTM. This finding is in line with Ajaja (2011), Dashne and Sinaa (2019), Woldeamanuel et al. (2020) who at various times and studies found that students improved 
significantly in their achievement in biology when taught using CM compared to those taught using CTM. However, this finding contradicts with that of Martins-Omole et al. (2016) who discovered that while the CM improved student performance, it was not significantly better than CTM.

Moreover, the findings showed that students who were taught using CML achieved significantly higher than their counterparts who were taught with CTM. This finding confirms the findings of Keter (2013) that the CML group achieved much more than the CTM group. The superiority of CML over CTM may be attributed to the fact that CML combined both potentials of cooperative and mastery learning methods. Cooperative learning provides students the opportunity to share ideas, collaborate, and refine concept understanding (Slavin, 2011). This is also supported by Vygotsky (1978) who contended that concepts can be developed as students communicate with each other through discussion in which students can operate at a higher cognitive level. Besides, the provision of corrective feedback in mastery learning promotes students' concept development and understanding as suggested by Bloom (1976). Likewise, students' learning in the CML group becomes non-competitive since it requires the assessment of students to be criterion-referenced (Khan\& Masood, 2015).

Furthermore, it was revealed that the students in $\mathrm{CM}$ group achieved significantly higher than those in CML. This finding is similar to that of Bot and Eze (2016) who found that students who were taught using CM performed better than those taught using cooperative learning strategy. The noticeable superiority of CM over CML in this study could be attributed to the presentation of the concepts in concept maps. The evidence from the literature has shown that the information is better remembered when it is communicated verbally and visually (Romero et al., 2017). Moreover, Novak and Cañas (2009) explained that the use of concept maps helps learners to organize new information to what they already know, thus, promotes long-term retention and recall of the information learned. Therefore, the observed difference between the CM and CML groups is the result of the $\mathrm{CM}$ being more effective in helping students visualize graphically the relationship between concepts.

The findings also indicated that there was an insignificant interaction effect of treatment and gender on students' achievement. This finding is consistent with that of Adeyemi and Cishe (2017), Çömek et al. (2016) in biology, science education, and basic science, respectively. However, this finding disagrees with the finding of Bot and Eze (2016) who found a significant interaction effect of treatment and gender on student achievement in Mathematics-Trigonometry.

The result of the t-test revealed that the students had a favourable attitude towards both methods, but they were more inclined to employ the CM than CML. This finding is in line with that of Luchembe et al. (2014), Martins-Omole et al. (2016) who revealed that students have positive attitudes towards the use of the CM in physics and biology respectively. The result also concurs with that of Keter (2013) which highlighted that the student's motivation to learn chemistry concepts was increased after being exposed to the CML. 


\section{Conclusion}

The study sought to find out the effects of CM and CML instructional strategies on students' achievement in photosynthesis and their attitudes towards these instructional strategies. Based on the findings, the use of the CM and CML helped students to score better in photosynthesis than the CTM. Besides, the use of the $\mathrm{CM}$ and $\mathrm{CML}$ in teaching and learning photosynthesis was genderbalanced since the two strategies gave equal opportunities to both sexes. Moreover, students had a favourable attitude towards both instructional strategies, but they were more inclined to employ the CM than CML for teaching photosynthesis. Therefore, the study revealed that the CM and CML are more effective in enhancing the achievement of students in photosynthesis and thus offers a remedy to the misconceptions that have affected students understanding of photosynthesis and other difficult biology concepts and to bridge the gap between gender disparities in students' achievement in biology. Therefore, secondary school teachers, particularly biology teachers, must be aware of the benefits of $\mathrm{CM}$ and $\mathrm{CML}$ and thus change the practice of teacher-centered teaching to learner-centered teaching methods, if improved outcomes are to be attained.

\section{Limitations and Recommendations}

Students in the CM group outperformed students in the CML and CTM groups by a wide margin. However, one out of 30 districts was studied and no students from day secondary schools were included in the study. Thus, further empirical research on the application of CM and CML on various topics in biology at various levels and in both boarding and day schools should be conducted to create a solid foundation for their implementation in secondary schools in Nyamagabe and other districts of Rwanda. Besides, a similar study on how biology teachers perceive the use of $\mathrm{CM}$ and CML in terms of implementation and feasibility in their classroom settings should be conducted. Nevertheless, biology teachers should be trained through seminars and workshops so that they can effectively integrate CM and CML as teaching strategies in biology classes and to enhance students' achievement in biology especially in difficult and abstract concepts like photosynthesis.

\section{References}

Aboho, D. A; Agbidye, A, \&Asooso, L. N. (2013). Developing curriculum on climate change at secondary school level in Nigeria. Nigerian Journal of Curriculum Studies, 20(2), 47-64.https:/ / bit.ly/3nsPEu5

Adeyemi, S. B., \& Cishe, E. N. (2017). Effects of cooperative and individualistic learning strategies on students' map reading and interpretation. Ghana Journal of Development Studies, 13(2), 154-175. https:// doi.org/10.4314/gjds.v13i2.9

Ajaja, O. P. (2011). Concept mapping as a study skill: Effects on students achievement in biology. International Journal Education Science, 3(1), 49-57. https://doi.org/10.1080/09751122.2011.11890008

Ajaja, O. P. (2013). Which strategy best suits biology teaching? Lecturing, concept mapping, cooperative learning, or learning cycle? Electronic Journal of Science Education, 17(1), 20-21. https:// bit.ly/3npCGwa

Akçay, S. (2017). Prospective elementary science teachers' understanding of photosynthesis and cellular respiration in the context of multiple biological levels as nested systems. Journal of Biological Education, 51(1), 52-65. 
https://doi.org/10.1080/00219266.2016.1170067

Angura, M. T., \& Abakpa, V. O. (2018). Impact of cooperative instructional strategies andconventional teaching methods on students' achievement and interest in upper basic education science and technology in Nigeria. International Journal of Innovative Research and Development, 7(2), 38-45. https://doi.org/10.24940/ijird/2018/v7/i2/jan18085

Awofala, A. O. (2016). Effect of concept mapping strategy on students ' achievement in junior secondary school. International Journal of Mathematics Trends and Technology-, 2(3), 11-16. https:/ / bit.ly/3rpzfrI

Bandura, A. (1977). Social learning theory. Englewood Cliffs, NJ: Prentice Hall.

Bloom, B.S. (1976). Human characteristics and school learning. McGraw-Hill.

Bot, T., \& Eze, J. (2016). Comparative effects of concept mapping and cooperative learning strategies on senior secondary school students' achievement in mathematics-trigonometry in Kano State, Nigeria. European Journal of Science and Mathematics Education, 4(1), 56-66. https://doi.org/10.30935/scimath/9453

Cohen, J. (1988). Statistical power analysis for the behavioral sciences (2nd ed.). Hillsdale, NJ: Lawrence Erlbaum Associates.

Çömek, A., Akınoğlu, O., Elmacı, E., \& Gündoğdu, T. (2016). The effect of concept mapping on students' academic achievement and attitude in science education. Journal of Human Sciences, 13(1), 348-363. https:// doi.org/10.14687/ijhs.v13i1.3558

Creswell, J. (2014). Research design: Qualitative, quantitative, and mixed methods approach (4th ed.). SAGE Publications, Inc.

Dashne, A. S., \& Sinaa, A. A. (2019). The effect of using concept mapping strategy on the achievement of eighth-grade school students in biology subject in Erbil city. Zanco Journal of Humanity Sciences, 23(2960), 127-147. https://doi.org/10.21271/zjhs.23.5.7

Etobro, A. B., \& Fabinu, O. E. (2017). Students' perceptions of difficult concepts in biology in senior secondary schools in Lagos State. Global Journal of Educational Research, 16(2), 139-147. https:/ / doi.org/10.4314/gjedr.v16i2.8

Fives, H., \& DiDonato-Barnes, N. (2013). Classroom test construction: The power of a table of specifications. Practical Assessment, Research, and Evaluation, 18(3), 1-7. https://doi.org/10.7275/cztt-7109

Goreyshi, M. K., kargar, F. R., Noohi, S., \& Ajilchi, B. (2013). Effect of combined masterycooperative learning on emotional intelligence, self-esteem, and academic achievement in grade skipping. Procedia-Social and Behavioral Sciences, 84, 470474. https:// doi.org/10.1016/j.sbspro.2013.06.586

Hadiprayitno, G., Muhlis, \& Kusmiyati. (2019). Problems in learning biology for senior high schools in Lombok Island. Journal of Physics: Conference Series, 1241(1). https://doi.org/10.1088/1742-6596/1241/1/012054

Hinton, P. R., McMurray, I., \& Brownlow, C. (2014). SPSS explained. Routledge.

Jia, C., Yang, T., Qian, Y., \& Wu, X. (2020). The gender differences in science achievement, interest, habit, and creativity: A national representative evidence from China. Science Education International, 31(2), 195-202. https:// doi.org/10.33828/sei.v31.i2.9

Joda, F. M. (2019). Effects of instructional scaffolding strategy on senior secondary biology students' academic achievement and retention in Taraba State, Nigeria. Science Journal of Education, 2(2), 269-275. https://doi.org/10.31014/aior.1993.02.02.59

Johnson, M. P. (2016). Photosynthesis. Essays in Biochemistry, 60(3), 255-273. https://doi.org/10.1042/EBC20160016

Keter, J. K. (2013). Effects of cooperative mastery learning approach on secondary school students' motivation and achievement in chemistry in Bomet County, Kenya [Master's 
thesis]. Egerton University.

Khan, F. M. A., \& Masood, M. (2015). The effectiveness of an interactive multimedia courseware with coMoperative mastery approach in enhancing higher-order thinking skills in learning cellular respiration. Procedia - Social and Behavioral Sciences, 176, 977-984. https://doi.org/10.1016/j.sbspro.2015.01.567

Kyado, J. J., O. Abah, C., \& Samba, R. M. A. (2019). Effect of collaborative concept mapping instructional strategy on secondary students' achievement in difficult biology concepts. American Journal of Social Sciences and Humanities, 4(3), 434-447. https:// doi.org/10.20448/801.43.434.447

Luchembe, D., Chinyama, K., \& Jumbe, J. (2014). The effect of using concept mapping on students' attitudes and achievement when learning the physics topic of circular and rotational motion. European Journal Of Physics Education, 5(4), 10-29. https://doi.org/10.20308/ejpe.21138

Martins-Omole, M. I., Yusuf, H. O., \& Guga, A. (2016). Effects of concept mapping and experimental techniques in teaching biology in secondary schools in Federal Capital Territory Abuja, Nigeria. European Journal of Education Studies, 2(6), 119130. https://bit.ly/3m4Wvd0

Métioui, A., Matoussi, F., \& Trudel, L. (2016). The teaching of photosynthesis in secondary school: A history of the science approach. Journal of Biological Education, 50(3), 275-289. https:// doi.org/10.1080/00219266.2015.1085427

Mokiwa, H. O., \& Agbenyeku, E. U. (2019). Impact of activity-based teaching strategy on gifted students: A case of selected junior secondary schools in Nigeria. Journal for the Education of Gifted Young Scientists, 7(3), 421-434. https://doi.org/10.17478/jegys.529919

Nasution, M. K. (2018). Student assessment and misconceptions of photosynthesis: A notion of shifting perspective. Journal As-Salam, 2(2), 106-112. https://doi.org/10.37249/as-salam.v2i2.39

Novak, J. D., \& Cañas, A. J. (2009). The development and evolution of the concept mapping tool leading to a new model for mathematics education. In K. Afamasaga-Fuata'i (Ed.), Concept mapping in mathematics (pp. 3-16). Springer. https://doi.org/10.1007/978-0-387-89194-1_1

Novak, J.D., \& Gowin, B., (1984). Learning how to learn. Cambridge University Press. https://doi.org/10.1017/CBO9781139173469

Romero, C., Cazorla, M., \& Buzón, O. (2017). Meaningful learning using concept maps as a learning strategy. Journal of Technology and Science Education, 7(3), 313-332. https://doi.org/https://doi.org/10.3926/jotse.276

Rwanda Education Board. (2015). Competency-based curriculum-summary of curriculum framework pre-primary to upper secondary. Ministry of Education. https:// bit.ly/30W3dd9

Schmid, R. F., \& Telaro, G. (2018). Concept mapping as an instructional strategy for high school biology. The Journal of Educational Research, 84(2), 78-85. https://doi.org/https://doi.org/10.1080/00220671.1990.10885996

Slavin, R. E. (2011). Instruction based on cooperative learning. Handbook of research on learning and instruction. https://doi.org/https://doi.org/10.4324/9780203839089-26

Stevenson, K. T., Szczytko, R. E., Carrier, S. J., \& Peterson, M. N. (2021). How outdoor science education can help girls stay engaged with science. International Journal of Science Education, 43(7), 1090-1111. https://doi.org/10.1080/09500693.2021.1900948

Uchegbue, H. O., \& Amalu, M. N. (2020). An assessment of sex, school type, and retention ability in basic technology achievement among senior secondary school students. Global Journal of Educational Research, 19(1), 1-7. https://doi.org/10.4314/gjedr.v19i1.2

Vygotsky, L. S. (1978). Mind in society: The development of higher psychological processes. 
Cambridge, MA: Harvard University Press.

Wang, Y., Chiou, C., Lee, L., \& Tien, L. (2017). Analyzing the effects of various concept mapping techniques on learning achievement under different learning styles. EURASIA Journal of Mathematics Science and Technology Education, 8223(7), 36873708. https://doi.org/10.12973/eurasia.2017.00753a

Woldeamanuel, Y. W., Abate, N. T., \& Berhane, D. E. (2020). Effectiveness of concept mapping-based teaching methods on grade eight students' conceptual understanding of photosynthesis at Ewket Fana Primary School, BahirDar, Ethiopia. Eurasia Journal of Mathematics, Science and Technology Education, 16(12), 1-16. https://doi.org/10.29333/ejmste/9276

\section{Appendix 1: Photosynthesis Achievement Test (PAT)}

1. Photosynthesis takes place in....

a) Autotrophic organisms

b) Primary consumers

c) Decomposers

d) Heterotrophic organisms

2. Which of the below statements is correct about the structural adaptation of leaf for photosynthesis:

a) The leaf cuticle and epidermis of the leaf are thick and transparent to allow easy penetration of sunlight into the leaf.

b) The leaf cuticle and epidermis are transparent and are made of many layers of cells to allow sunlight to be absorbed easily.

c) The leaf cuticle and epidermis are thin and transparent to allow easy penetration of light.

d) The leaf cuticle and epidermis are transparent and dense to allow easy penetration of the light into the leaf.

3. Photosynthesis is the process in which plants produce:

a) Carbohydrates and oxygen

b) Sugar and carbon dioxide

c) Starch and carbon dioxide

d) Chlorophyll and radiant energy

4. One of the following is not a necessary condition for Photosynthesis to take place, which one?

a) Availability of Water.

b) Presence of Sunlight

c) An adequate supply of Oxygen

d) Presence of Chlorophyll

5. Which pair of substances are the raw materials photosynthesis?

a) Oxygen and organic matter

b) Oxygen and water

c) Carbon dioxide and organic matter 
d) Carbon dioxide and water

6. The most important benefit to green plants when they photosynthesize is:

a) Removal of carbon dioxide

b) Conversion of light energy to chemical energy

c) Production of energy

d) Production of oxygen

7. What type of energy do plants receive from the sun?
a) Chemical energy
b) Light energy
c) Geothermal energy
d) Electrical energy

8. Which gas is taken by green plants in large amounts when there is no light energy at all?
a) Carbon dioxide gas
b) Oxygen gas
c) Nitrogen gas
d) Neo gas

9. In which part of the plant does photosynthesis take place most?
a) In the whole plant
b) In the roots
c) In the leaves
d) In the stem

10. Which pair of substances are the reactants in photosynthesis and which substances are products of photosynthesis?

a) Reactants are oxygen and water, and products are glucose in oxygen

b) Reactants are oxygen and water, and products are oxygen and water

c) Reactants are carbon dioxide and organic matter, and products are glucose in oxygen

d) Reactants are carbon dioxide and water, and products are glucose and oxygen

11. Which part of the plant contains chlorophyll and in which part of the plant does photosynthesis take place?

a) Chlorophyll is in the leaves, and photosynthesis takes place in the whole plant

b) Chlorophyll is in the roots, and photosynthesis takes place in the leaves

c) Chlorophyll is in the leaves, and photosynthesis takes place in the leaves

d) Chlorophyll is in green parts of the plant, and photosynthesis takes place in the green parts of the plant 
12. What type of energy do plants receive from the sun and into what type of energy do plants transform sunlight energy?

a) Plants receive chemical energy from the sun and transform it into chemical energy

b) Plants receive light energy from the sun and transform it into movement

c) Plants receive light energy from the sun and transform it into chemical energy

d) Plants receive light energy from the sun and transform it into light energy

13. Which of the following is the correct photosynthesis equation?

a) $\quad 6 \mathrm{CO}_{2}+\mathrm{C}_{6} \mathrm{H}_{12} \mathrm{O}_{2}+$ light energy

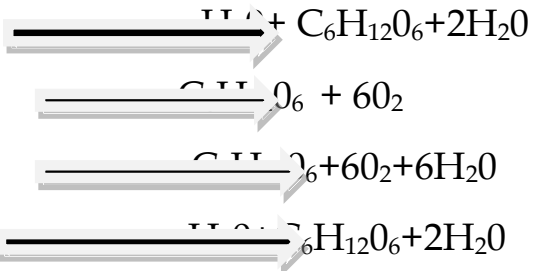

14. For photosynthesis to occur, a plant requires...

a) Water, oxygen, light, and chlorophyll

b) Chlorophyll, light, carbon dioxide, and oxygen

c) Carbon dioxide, light, chlorophyll, and water

d) light, darkness, oxygen, and carbon dioxide

15. Which of the following atmospheric gases will disappear first if all chlorophyll-containing in plants were to be removed?
a) Nitrogen
b) Carbon dioxide
c) Oxygen
d) Water vapor

16. The net reaction for photosynthesis produces:
a) Water and carbon dioxide
b) Water and Oxygen
c) Carbohydrate and carbon dioxide
d) Carbohydrate and Oxygen

17. A well-watered potted green plant is kept in a brightly lighted area for 48 hours. What will most likely occur if the light intensity is then reduced slightly during the next 48 hours?

a) Photosynthesis will stop completely.

b) The rate at which nitrogen is used by the plant will increase.

c) The rate at which Oxygen is released from the plant will decrease.

d) Glucose production inside each plant cell will increase. 
18. A plant with pink leaves and stem is capable of photosynthesizing because of it:

a) has special cells that can photosynthesize.

b) has chlorophyll which has been masked.

c) uses the pink pigment to photosynthesize.

d) possesses carotene which is efficient in photosynthesizing.

19. The deficiency of nitrate ions results to:
a) Poor synthesis of chlorophyll
b) Yellowing of the leaf
c) Stunted growth
d) All the above

20. Variegated leaf is used in an experiment to show that:
a) Water is essential for photosynthesis
b) Sunlight is necessary for photosynthesis
c) Chlorophyll is necessary for photosynthesis
d) Carbon dioxide is essential for photosynthesis

21. The type of cells which absorb most carbon dioxide during the day are:
a) Palisade mesophyll cells
b) Guard cells
c) Epidermal cells
d) Mitochondria cells

22. The entrance where gas exchange occurs into and out of the leave is called:
a) Guard cell
b) Palisade cell
c) Stomata
d) Mesophyll cell

23. One of the mineral ions required for the synthesis of Chlorophyll is:
a) Magnesium ions
b) Sodium ions
c) Potassium ions
d) Calcium ions

24. The cells which are responsible for the control of the entrance of air into and out of leave is:
a) Guard cells
b) Epidermal cells
c) Mesophyll cells
d) Palisade cells

25. What causes plants to be usually green in color?
a) Photosynthesis
b) Chlorophyll 

c) Starch
d) Glucose

26. The two major raw materials of photosynthesis are:
a) Water and carbon dioxide
b) Carbon dioxide and sugar
c) Oxygen and carbon dioxide
d) Water and oxygen

27. Which of the following cells of the leaf lack chloroplasts?
a) Guard cells
b) Epidermal cells
c) Palisade mesophyll cells
d) Spongy mesophyll cells

28. An inorganic molecule required by green plants for the process of photosynthesis is
a) Oxygen molecule
b) Starch
c) Carbon dioxide
d) Glucose

29. Carbon dioxide is removed from the atmosphere through:
a) Respiration
b) Photosynthesis
c) Decomposition
d) Breathing

30. The principal transport vessel for the transport of water in plants is
a) Phloem
b) Lenticels
c) Xylem
d) Midrib

31. The role of vascular bundles in photosynthesis is to:
a) Trap sunlight energy
b) Allow sunlight to penetrate the leaf
c) Transport manufactured food and water
d) Absorb carbon dioxide

32. Which could be used to monitor the rate of photosynthesis in a plant?
a) Carbon dioxide
b) Water production
c) Oxygen production
d) Hydrogen production 
33. Which words are missing from the equation for photosynthesis?

Carbon dioxide $(\mathrm{CO} 2)+$ + sunlight ---> sugar +
a) Sugar, nitrogen
b) Energy, water
c) Water, oxygen
d) Oxygen, carbon dioxide

34. Which of the following does not affect the rate of photosynthesis
a) Carbon dioxide concentration
b) Light intensity
c) Oxygen concentration
d) Temperature

35. As a result of photosynthesis,

a) our atmosphere is now rich in oxygen gas.

b) animals can get energy directly from the sun.

c) plants convert chlorophyll into water

d) Abundant quantities of carbon dioxide are produced

36. The principal transport vessel responsible for the transporting of the end product of photosynthesis is
a) Phloem
b) Xylem
c) Midrib
d) Lenticels

37. The diagram represents a cross-section of a leaf.

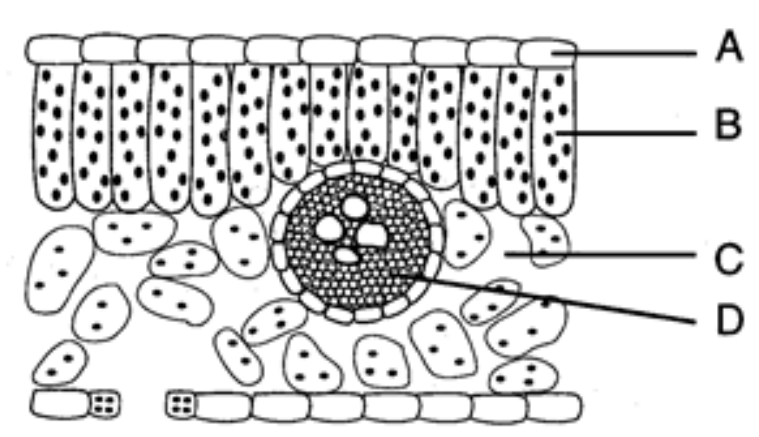

Which cell type absorbs most carbon dioxide during the day?
a) $\quad \mathrm{A}$
b) B
c) $\quad \mathrm{C}$
d) $\quad \mathrm{D}$

38. For photosynthesis green plants require:
a) Chlorophyll only
b) Light 
c) Carbon dioxide and water

d) All of the above

39. The name of the pigment which is responsible for the absorption of light in plants is:
a) Stroma
b) Chlorophyll
c) Xylem
d) Phloem

40. The following diagram shows the effect of light intensity on the rate of photosynthesis

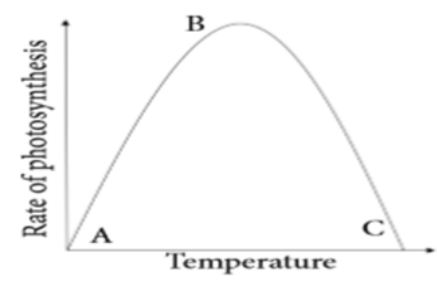

In the above diagram, the rate of Photosynthesis started to decrease from point $B$ to $C$. Which of the below statements best describe the main cause of the above decrease:

a) The increase of temperature above the optimum point cause the breakdown of some biological catalysts which in turn led to a decrease in the rate of photosynthesis.

b) The increase in temperature above the optimum point has caused a shortage of water through evaporation, which in turn leads to a decrease in the rate of photosynthesis.

c) The temperature above the optimum point has caused the breakdown of chemical bonds in chlorophyll which in turn led to a decrease in the rate of photosynthesis.

d) All above

\section{Appendix 2: Attitude Towards Concept Mapping Questionnaire (ATCMQ)}

INSTRUCTION: To respond to this questionnaire, please put a checkmark $(\sqrt{ })$ in the appropriate box to indicate your level of agreement or disagreement with the statements: 1 (strongly disagree); 2 (disagree); 3 (neutral); 4 (agree); and 5 (strongly agree)

\begin{tabular}{|l|l|l|l|l|l|l|}
\hline No & Statement & $\mathbf{1}$ & $\mathbf{2}$ & $\mathbf{3}$ & $\mathbf{4}$ & $\mathbf{5}$ \\
\cline { 2 - 7 } & Interest & & & & & \\
\hline 1 & Concept mapping makes Biology class & & & & \\
\hline
\end{tabular}




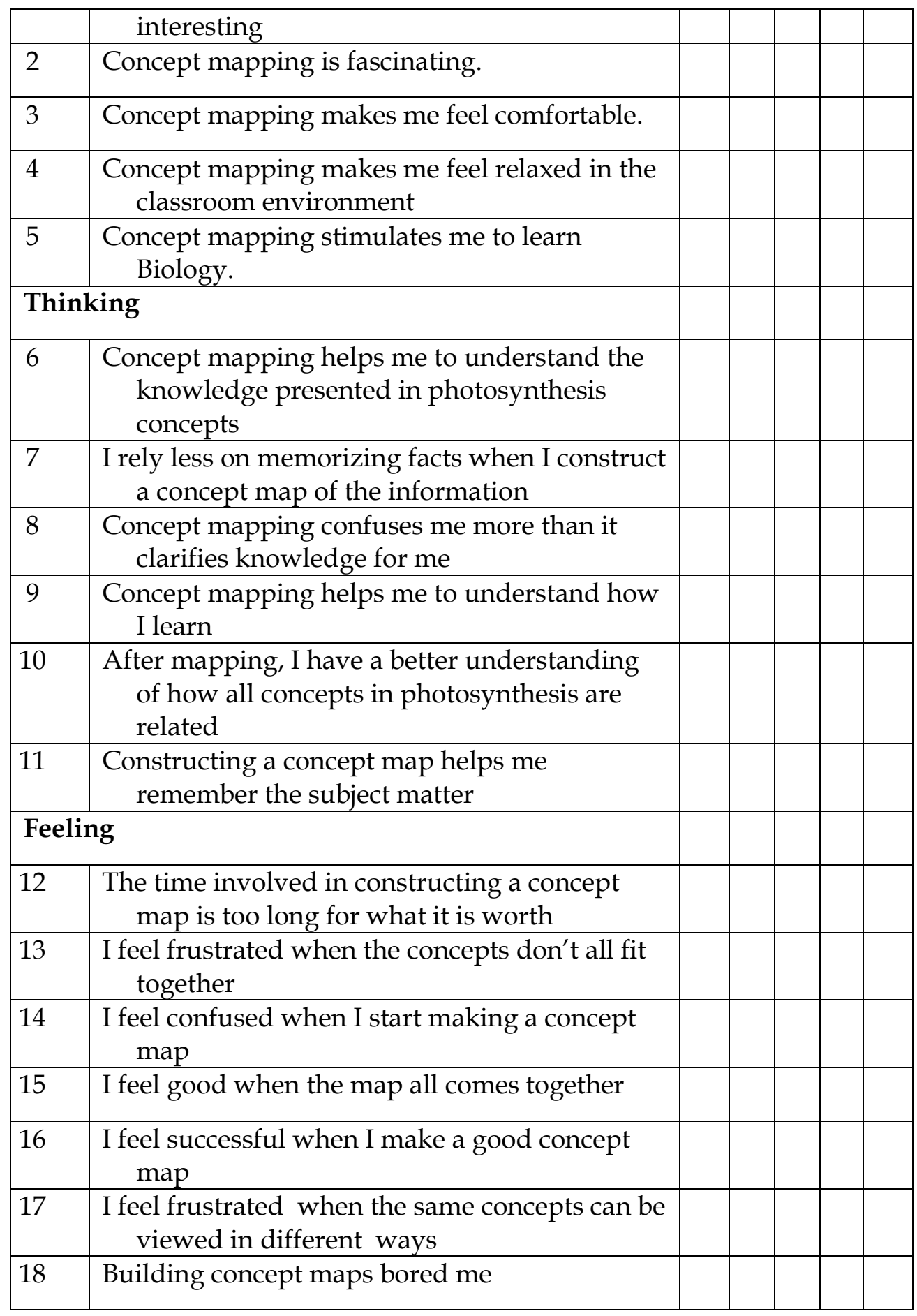

1. How do you think the Concept Mapping contributed to your understanding of photosynthesis? Please briefly explain your answer 
2. How do you rate your understanding of photosynthesis?

a) Very good

b) Good

c) Satisfactory

d) Unsatisfactory

\section{Appendix 3: Attitudes Towards Cooperative Mastery Learning Questionnaire (ATCMLQ)}

INSTRUCTION: To respond to this questionnaire, please put a checkmark

$(\sqrt{ })$ in the appropriate box to indicate your level of agreement or disagreement with the statements:

1 (strongly disagree); 2 (disagree); 3 (neutral); 4 (agree); and 5 (strongly agree)

\begin{tabular}{|c|c|c|c|c|c|c|}
\hline No & Items & 1 & 2 & 3 & 4 & 5 \\
\hline & Interest & & & & & \\
\hline 1 & $\begin{array}{l}\text { Cooperative mastery learning makes Biology } \\
\text { class interesting }\end{array}$ & & & & & \\
\hline 2 & Cooperative mastery learning is fascinating. & & & & & \\
\hline 3 & $\begin{array}{l}\text { Cooperative mastery learning makes me feel } \\
\text { comfortable. }\end{array}$ & & & & & \\
\hline 4 & $\begin{array}{l}\text { Cooperative mastery learning makes me feel } \\
\text { relaxed in the classroom environment }\end{array}$ & & & & & \\
\hline 5 & $\begin{array}{l}\text { Cooperative mastery learning stimulates me to } \\
\text { learn Biology. }\end{array}$ & & & & & \\
\hline \multicolumn{6}{|c|}{ Thinking } & \\
\hline 6 & $\begin{array}{l}\text { I understand information better when I work } \\
\text { with others in a cooperative mastery learning } \\
\text { group }\end{array}$ & & & & & \\
\hline 7 & $\begin{array}{l}\text { I try harder knowing that other group members } \\
\text { are depending on me }\end{array}$ & & & & & \\
\hline 8 & $\begin{array}{l}\text { Listening to other ideas and points of view helps } \\
\text { me understand. }\end{array}$ & & & & & \\
\hline 9 & $\begin{array}{l}\text { Cooperative mastery learning group members } \\
\text { learn more when different points of view are } \\
\text { challenged }\end{array}$ & & & & & \\
\hline 10 & $\begin{array}{l}\text { The more I explain ideas to others, the more I } \\
\text { lean }\end{array}$ & & & & & \\
\hline 11 & $\begin{array}{l}\text { Some ideas are explained better by my peers } \\
\text { than by my teacher }\end{array}$ & & & & & \\
\hline 12 & I learn best when I work independently & & & & & \\
\hline \multicolumn{7}{|c|}{ Feeling } \\
\hline 13 & I am a valuable member of my group & & & & & \\
\hline 14 & Other group members have interesting & & & & & \\
\hline
\end{tabular}




\begin{tabular}{|l|l|l|l|l|l|}
\hline & information to offer. & & & & \\
\hline 15 & I prefer to compete rather than cooperate & & & & \\
\hline 16 & Other group members want me to be successful & & & & \\
\hline 17 & It is upsetting when others don't agree with me & & & & \\
\hline 18 & $\begin{array}{l}\text { Working cooperatively puts too much pressure } \\
\text { on me and the other group members }\end{array}$ & & & & \\
\hline
\end{tabular}

1. How do you think Cooperative Mastery Learning contributed to your understanding of photosynthesis? Please briefly explain your answer

2. How do you rate your understanding of photosynthesis?

a) Very good

b) Good

c) Satisfactory

d) Unsatisfactory 